\title{
THE TOBACCO MONOPOLY: THE WORLD AND DOMESTIC EXPERIENCE
}

\author{
Oksana Pasitska \\ Department of Contemporary History \\ Ivan Krypyakevych Institute of Ukrainian Studies, National Academy of Sciences of Ukraine \\ 4 Kozelnytska str., Lviv, Ukraine, 79026 \\ pasitska@ukr.net
}

\begin{abstract}
The article analyses the historical and economic development of the tobacco market from its cultivation in America to the formation and operation of monopolies in European countries. The features of the tobacco market in Ukraine, from the time of origin until now, are studied. Researches testify to the fact that tobacco cultivation began in America, and in the sixteenth and seventeenth centuries tobacco production became common all throughout Europe. There were three main historical and economic ways that tobacco was brought to Ukraine: from China, Turkey and European countries. Major tobacco plantations were located in Poltava and Kherson regions, eastern Galicia and Podilia, etc. First tobacco factories as well as trading departments came into operation in the eighteenth and nineteenth centuries. As far as tobacco industry developed by leaps and bounds and brought substantial profit, tobacco production and sales volume of tobacco products were controlled on the state level by means of excise taxes and monopolies. In the first third of the twentieth century, there was a number of monopolies (among them Austrian, Polish, Hungarian, Russian and some other) that were quite successful. After the Second World War tobacco industry in Ukraine could develop on the basis of tobacco factories in Lviv, Kyiv, Cherkasy, Kharkiv, Zhmerynka, etc. and due to the import of tobacco products. In the twenty-first century, tobacco market in Ukraine has to undergo some major changes on both legislative and practical levels.

The results of this study are important for understanding the history of tobacco industry on national and international levels.

Keywords: cultivation of tobacco, the tobacco monopoly, labour relations, factory, production, tobacco products.
\end{abstract}

\section{Introduction}

The studying of each industry allows analyse the world economic development. The tobacco market has centuries-old socio-economic features. On the one hand, tobacco is harmful for human health, on the other, it is an important source of financial revenue to the budget of any state. Therefore the tobacco industry needs the government control. State tobacco monopolies started operating in the 19th century. The studying of these monopolies provides the better understanding of the historical and economic prospects for the tobacco industry on Ukrainian lands and the economic policy of Ukraine at the present stage.

\section{Literature review}

Tendencies in the development of tobacco monopoly enterprises became the subject of the study "The economic and legal framework for the regulation of economic activities of the tobacco industry enterprises in Ukraine" [1]. Economic and historical aspects as well as forming and functioning stages of the tobacco market on the international level, and the development of the Ukrainian tobacco subcomplex is the subject of dissertation "The economic mechanism of tobacco market functioning in Ukraine" [2]. Given study highlights the specific historical and economic aspects of the tobacco market development without paying due attention to state owned tobacco monopolies. General aspects of the tobacco industry are covered in encyclopedias [3]. A brief botanical description and history of tobacco cultivation is provided in such works as "Tobacco from the historical, chemical, and toxicological point of view" [4], "Tobacco production in Ukraine" [5], "Tobacco: its cultivation and preparation for sale" [6] and "Tobacco and its consequences" [7]. Establishing and peculiarities of development of the Polish tobacco monopoly in 1920s and 1930s are highlighted with the help of the archival documents and publications, e. g. "The Polish Tobacco Monopoly 1919-1925" [8], "The Polish Tobacco Monopoly as an employer" [9], "The Polish Tobacco Monopoly 1926-1927” [10], “The Polish Industry and Trade. The address and information book 
of industry, trade, and finance enterprises in the Polish Republic" [11]. However, tobacco monopoly has not been studied as a separate historical and economic phenomenon in historiography yet.

\section{The aim and objectives of research}

The purpose of the article is to show the development of tobacco industry from the tobacco cultivation stage to the period of state tobacco monopolies activities, outlining peculiar historical and economic features of tobacco industry in Ukraine.

To achieve this goal the following tasks have been set:

- highlight the historical and economic ways of tobacco cultivation and development of the world tobacco market;

- investigate the process of formation and operation of tobacco monopolies;

- analyse the history of tobacco industry in Ukraine.

\section{Materials and methods of research}

The methodological basis of the given study stems from the principles of historicism and objectivity. Economic theory methods were used along with general and special historical methods, namely deduction, induction, generalization and systematization of historical facts, comparative analysis, system functional analysis, etc., as well as methods of mathematical statistics. Problem-chronological approach was used to present the collected material.

\section{Summary of the basic material and its study}

The tobacco monopoly is one of the most common financial monopolies. It is global, and the tobacco industry has been considered as one of the most lucrative sectors of the economy for the past several centuries. The concentration and centralization of capital and production have become the economic basis for the operation of tobacco monopolies. A monopoly on tobacco is characteristic of many European countries, and tobacco enterprises are one of the most investment attractive.

A special monopoly on tobacco products has its backstory. The cultivation of tobacco begins in the 16th century. They say that when navigator Christopher Columbus came to America, Aboriginals presented him dried leaves of a plant "petum" which they rolled in tubes and smoked, calling such tubes "a cigar". The seeds of this plant were brought to Spain after the second voyage of Columbus. The plant got its name from the province of Tobago (island of Haiti). According to another version, the Spanish monk Romano Pane saw this plant in Santo-Domingo in 1496. He described the properties of tobacco in one of his letters which he sent to Europe. In 1511 Romano Pane's letter was published for general consumption [4]. In 1520 the court physician of the King Philip II Francisco Hernandez brought the plant from America to Spain and Portugal. In 1560 the French ambassador of the Portuguese court Jeon Nicot sent a tobacco plant to the Queen of France Catherine de Medici (Nicotiana tabacum - named in honour of the ambassador) from Lisbon. In 1563 tobacco came to Poland from Turkey. The same year, the professor of the Krakow Academy Marcin Siennik described the properties of this plant. In 1566 tobacco came to Germany thanks to an inhabitant of Augsburg Adolf Okko [7].

Originally, tobacco was used during religious rituals, and later as a medical plant (to cure headache, eye pain, toothache, apply to wounds, including burns), and later for snuffing, chewing, smoking. In 1615 the first mention of processing tobacco as an industry plant in Amersfoort (the Netherlands) appeared $[4,5]$. The tobacco production spread by rapid leaps throughout Europe, Africa, Asia and the World.

By the way, it was prohibited to use tobacco for smoking in many countries. For example, Elizabeth, the Queen of England, was one of the first strong opponents of the cultivation and trade of tobacco. France also prevented the expansion of tobacco smoking. People who smoked were sentenced to death in European cities of Bern and Lüneburg. Originally, tobacco was considered "the devil's toy" in Italy. Popes even offered to unchurch people who smoked or snuffed tobacco. In the 16th century smokers were also persecuted in England. In 1604 the King James Stewart took the throne and declared the smoking "harmful, impious, and unworthy of a civilizational human being occupation". The King wrote the tractate "A Counterblaste to Tobacco", which ends with the 
words: "A custome lothsome to the eye, hatefull to the Nose, harmefull to the braine, dangerous to the Lungs". It was the first popular book about the harmfulness of smoking" [4, 6].

Despite a series of denials and harmfulness for human body the rate of tobacco trade and size of tobacco plantings were growing. At the end of the 16th century almost all European states cultivated tobacco, gradually introducing a monopoly. In 1834 France grew about $11.500 .000 \mathrm{~kg}$ of tobacco leaf in a year, Austria grew $20.000 .000 \mathrm{~kg}$, Hungary grew $2.720 .000 \mathrm{~kg}$, Portugal grew $1.300 .000 \mathrm{~kg}$ ( 1 kilogram= about 250 pieces of leaves). Tobacco trade produced considerable revenue, and prices of tobacco were growing every year. For example, in 1850 revenues from the sale of tobacco totalled 122.068.401 Francs in France, in 1860 it was 187.400.000 Francs, and it was about 8 million pound sterling in England. As of 1863 the tobacco companies of the Austrian Empire had a great production potential, their annual output was more than 850 million pieces of cigars of different types $[7,10]$. At the beginning of the $20^{\text {th }}$ century the largest tobacco plantations were in the USA, India, and the Russian Empire The tobacco industry in the Russian Empire produced $2.5 \%$ of all the state revenues in 1913; in 1922 the tobacco excise duty came up to $7.7 \%$ of all taxes [5, 6-10].

For centuries the tobacco production in Ukraine has been of great importance for the development of agriculture. It is accepted that the Ukrainians got a tradition of cultivating tobacco from the Tatars, and the Ukrainian name "tyutyun" is of Turkish origin [5-6]. A contemporary economist Yevgeny Mykhaylov claims that the tobacco market in Ukraine was formed many centuries ago, historical and economic ways tobacco came to Ukraine are different: it got to the left-bank Ukraine from China, to the Crimea from Turkey and Persia, to the right-bank Ukraine from the countries of Europe [2, 6]. Most tobacco plantations were situated in Poltavshchyna, Kharkivshchyna, in the Eastern Galicia, Podillya, Khersonshchyna, Katerynoslavshchyna, Tavriya. The tax exemption privilege, given by Vladyslav IV to Pereyaslavl, evidenced that the tobacco market existed in Ukraine. In 1661 the Moscow government begins to fight tobacco smoking and issues several strict orders, prohibiting the import of tobacco into Ukraine. However, the prohibition was local. In 1717 at the order of Peter I the first in Ukraine and in the Russian Empire tobacco factory was built in Okhtyrka (Kharkivshchyna) that grew the best types of tobacco [3].

It is known that, according to the official data, more than 1.5 million $\mathrm{kg}$ of tobacco crop was harvested in 1723 from 83 "hundreds" (1 "hundred"=1 are $=0.01$ hectare) of Hetmanshchyna. Not only Cossacks but also other social groups cultivated tobacco. In the 18th century the Markovych family, Polubotok, Skoropadsky, Myloradovych, Kochubei, Gorlenko, and others had big tobacco plantations $[5,9]$.

Later a number of small tobacco factories appeared. In the second half of the 19th century tobacco and common tobacco industry began to grow. At the beginning of the 20th century several tobacco joint-stock companies were created in the Russian Empire and in Ukraine. A syndicate, which concentrated about $75 \%$ of the cigarette production, appeared in 1913. In 1913109 tobacco and common tobacco factories, which employed about 6000 workers, acted in Ukraine (9 provinces). They produced 3.1 billion cigarettes (12\% of all the products in the Russian Empire). In 19111883 tons of common tobacco and 194 tons of tobacco were produced in 8 Ukrainian provinces. The common tobacco production was centered in small enterprises in the places of the common tobacco production, and the tobacco production was centered mainly in the larger cities (Odesa, Kyiv, Kremenchuk). Ukraine processed not only its own tobacco but imported tobacco too. The Ukrainian factories exported part of their production to other areas of the Russian Empire, even abroad. In the 1920-1930s a considerable concentration in the tobacco industry took place [3].

At the beginning of the 18th century the active tobacco cultivation in Galicia began. A commercial direction was developing instead of a consumer one in tobacco production. For the most part it was grown for sale. "Tobacco takes little place, but plugs many holes" - these were the words farmers described a tobacco as a culture that gave a great yield per unit [5]. Cultivation of tobacco required intensive care. The Turkish proverb says: “Tobacco makes a master's eye [5]. Even a tobacco duty was introduced, therefore every farmer gave a certain amount of tobacco leaf to the owner of the land. From the middle of the 18th century tobacco has been grown for industrial needs. Registration books recorded tobacco watchmen; and it indicates that there were tobacco plantations in Ukraine, and that magnates produced tobacco products. The first shops and factories for process- 
ing tobacco leaf were created, a tax on tobacco was introduced. In 1778 a tobacco monopoly was introduced in Galicia, after it had become a part of Austria; and in 1784 Emperor Joseph II issued the tobacco patent. The State began to control the production and circulation of tobacco products, purchased private tobacco factories. In the 1930s of the 19th century the Austrian Tobacco Monopoly was formed. It owned five tobacco factories: in Vynnyky, Krakow, Monastyryska, Yagilnytsia, Zabolotiv; trade departments in Lviv, Stanislaviv, Kolomyia, Peremysl, Rzeszow, Nowy Sacz, Wadowice. In Galicia, the tobacco companies in Zabolotiv, Monastyryska, Yagilnytsia, and the office of purchasing tobacco in Borshchovychi [5-6, 8] purchased and fermented raw materials. The tobacco companies of the country employed a lot of manual workers. In particular, the largest tobacco factory in the Western Ukraine - Vynnyky factory - employed 1230 workers (962 women and 268 men) in 1886. Every year their number was growing, and as of 1910 it was over 1500 people that showed the intensive development of the tobacco industry $[5,12]$.

At the beginning of the 20th century tobacco production produced the considerable revenue for a state: with the help of the excise duty in the Russian Empire, and with the help of the tobacco monopoly in Austria-Hungary. The First World War negatively affected the economic situation of the region. Almost all of the tobacco factories of the Austrian tobacco monopoly, except Krakiv tobacco company, suffered damage.

In 1918 the property of the Austrian tobacco monopoly got into the ownership of the Polish authorities. The Polish State began to control profits from taxation of tobacco production. For this purpose the Directorate of Polish tobacco monopoly in Warsaw was created in 1919. Polish tobacco monopoly began its activity with the Krakow tobacco factory. Later, with the support of the Ministry of Treasure, the Polish Tobacco Monopoly took a clear position on the reconstruction of factories and departments of tobacco trade in Zabolotiv, Monastyryska, Yagilnytsia, Borshchiv (territory of Galicia), construction of new factories in Warsaw, Lodz, Radom (a city in the central part of Poland), and the purchasing of private factories in Kovel (Volyn area) and Poznan (city in the Western Poland) [5, 9].

In 1919 about 470 thousand kilograms of tobacco raw materials were processed at the factories of the Polish Tobacco Monopoly, and in 1925 it was more than 17 million $\mathrm{kg}$ of tobacco, which was used for producing 56 million pcs. cigars, about 8 billion cigarettes, 12 million kg of tobacco [10].

As of 1926 the Polish tobacco monopoly owned 22 tobacco factories and a significant number of trade departments, which employed approximately 13 thousand regular workers and 3 thousand temporary and seasonal workers [11]. The tobacco companies have used both local and foreign tobacco (Brazilian, Greek, English, American, etc.). Turkish and English tobacco was in great demand [1-3, 13]. A significant number of tobacco products were imported from abroad.

The Polish Tobacco Monopoly had close economic ties with Hungarian, Yugoslav, Russian tobacco monopolies. For example, in 1925 about 4 million $\mathrm{kg}$ of tobacco were purchased in Yugoslavia, 350 thousand $\mathrm{kg}$ were purchased in Hungary, 660 thousand $\mathrm{kg}$ were purchased in the USSR. One of the conditions of trade relationship between tobacco monopolies was exchange of tobacco for local products (oil, salt, etc.) [8].

The tobacco industry has quickly developed in other countries too. For example, from 1 July 1923 to 30 June 1924 monopolistic tobacco factories in Hungary processed about 31 million $\mathrm{kg}$ of tobacco, in 1923 factories in the Austrian Republic processed about 17 million $\mathrm{kg}$ of tobacco, factories in Czechoslovakia processed more than 20 million $\mathrm{kg}$ of tobacco [8].

In 1939 the Polish Tobacco Monopoly, like other monopolies, was eliminated. In the postwar period the production of tobacco products on Ukrainian lands continued to develop through the activities of tobacco factories (the largest of them are Lviv, Kyiv, Cherkasy, Pryluky and Kharkiv ones), tobacco-fermentation plants (the largest are Zhmerynka, Simferopol, Berehove and Borshchagiv ones), and others. In 1978, 7.1 billion cigarettes were produced in the USSR, that is $20 \%$ of the All-Union production [3]. At the moment, the Ukrainian tobacco market is not balanced; the difference between supply and demand of home-produced cigarettes is covered by legal and illegal imports of tobacco products from Russia, Moldova, exports of surplus production to the EU. Tobacco subcomplex annually provides more than $3 \%$ of the state budget. Almost a half of Ukrainian population smokes (the first place in Europe and the eighth place in the world) [2]. In 2000 the 
domestic tobacco companies produced about 58 billion pieces of cigarettes, mostly in big tobacco companies in Kyiv, Pryluky, Kharkiv, Kremenchuk, Cherkasy [1].

At the moment, the tobacco market in Ukraine requires balancing by means of the production of Ukrainian raw materials, making changes to the legislation that would regulate mechanisms, setting quotas, licensing of production, export and import.

\section{Discussion of the results}

Practical significance of this study is that the material of the paper can be used in some areas of scientific research (when writing articles on world history and economics) as well as socioeconomic and regional studies. The findings of this study can be used for the further analysis of the problems related to the socio-economic history of Ukraine and economic history of the world.

\section{Conclusions and perspectives of the research}

Numerous researches have proved:

1. Tobacco cultivation began in America, and later tobacco production spread throughout the territory of Europe. In the nineteenth century tobacco market witnessed substantial changes, including the switch from free competition to the operation of monopolies.

2. In the nineteenth and twentieth centuries syndicates became an important component of economic development in European countries, including Austrian and Polish tobacco monopolies, which had a clear organizational structure and functioned on the basis of regulations (patents, laws), which made centralization of capital and production legal.

3. Since 1940s tobacco companies in Lviv, Kyiv, Pryluky, Kharkiv, Kremenchuk and Cherkasy were engaged in tobacco production. At present, tobacco market in Ukraine requires the precise balancing on both legislative and practical levels.

\section{References}

[1] Minenko, M. (2002). The economic and legal framework for the regulation of economic activities of the tobacco industry enterprises in Ukraine. Kyiv, 211.

[2] Mykhaylov, Y. (2009). The economic mechanism of the tobacco market functioning in Ukraine. Kyiv, 20.

[3] The Encyclopedia of Ukrainian Studies (2000). Lviv, 9.

[4] Karcz, M. (1888). Tobacco from the historical, chemical, and toxicological point of view. Lviv: Galician Pharmaceutical Society. The Printing House of "Gazeta Narodowa".

[5] Rensky, M. (1925). Tobacco production in Ukraine. Kharkiv: Knyhospilka.

[6] Didorenko, V. (1924). Tobacco: its cultivation and preparation for sale. Lviv: The Basilian Printing House in Zhovkva.

[7] Tobacco and its consequences (1878). Warsaw: Printed by Jozef Kaulman.

[8] The Polish Tobacco Monopoly 1919-1925 (1926). Warsaw: State Printing House in Warsaw.

[9] The Polish Tobacco Monopoly as an employer (1929). The third edition. Poznan: Polish Tobacco Monopoly Directorate.

[10] The Polish Tobacco Monopoly 1926-1927 (1928). Edition of the Polish Tobacco Monopoly. Warsaw: The State Printing House, 2.

[11] Goldman, A. (1930). The Polish Industry and Trade The address and information book of industry, trade, and finance enterprises in the Polish Republic. Warsaw-Lviv: The Chamber of Commerce and Industry.

[12] The Polish tobacco monopoly, 1922-1939, piece number 1, item number 1 (2001). Circulatory letters, instructions, correspondence, and other documents of the tobacco factory in the village of Vynnyky on conditions on tobacco factories. 1886-1903, 1922-1939. The Central State Historical Archives of Ukraine. Lviv: 443, 138.

[13] Reports on the purchasing and processing raw materials at the tobacco factory in the village of Vynnyky (1921). The Central State Historical Archives of Ukraine in Lviv, 443, 1, 2, 1-3. 